\title{
MORAL PORNOGRAPHY OR ETHICAL RHETORIC?
}

\author{
FREDERIC REGARD
}

Ecole Normale Supérieure des Lettres et Sciences Humaines

\begin{abstract}
This paper is concerned with the literary implications of Judith Butler's views on pornography. Butler chooses to argue againts a restrictive view of the performativity of injurious speech. She notes that pornography charts a domain of unrealizable positions and that the phantasmatic power of signs cannot, strictly speaking, constitute that reality. Butler also contemplates the possibility of a counter-speech, a kind of talking back that would implicate the emergence of an agency. Drawing on Angela Carter's famous theoretical essay on the marquis de Sade, I want to add grist to Butler's mill, but also to suggest that the production of an agency can only be achieved if the talking back has a rhetorical dimension, that only rhetoric can constitute an appropriate tool to fight back the threat of injurious speech. I henceforth suggest that Carter's contentious analysis of Sade as a "moral pornographer" should be best described as a theory of ethical rhetoric.
\end{abstract}

Can pornography be moral? How is the explicit description of sexual organs and activity to be reconciled with the practice of moralizing, i.e. of commenting on issues of right and wrong? Can the exploitation of sex slaves take on an exemplary dimension? The obvious answer to this question is No. Pornography cannot possibly be moral. For pornography is eminently injurious: it hurts a class of people, damages the very idea of human subjectivity. And yet, and yet. Consider this: did a self-branded feminist novelist like Angela Carter (1993: 19) not write an essay in which she defined the marquis de Sade as a "moral pornographer"? I am referring you to Carter's "Polemical Preface" in The Sadeian Woman. But precisely, the "Preface" overtly 
signals itself as "polemical": Carter is obviously highly aware of the cultural context of the day, and she knows that what she has to say concerning pornography runs up against the feminist doxa. She knows that pornography is generally perceived as one of the most blatant symptoms of the phallocentric functioning of society, that pornography not only exploits women, but also dehumanizes them by transforming them into commodities. This aspect of pornography, strangely enough, is acknowledged by Carter (1993: 3), whose very first sentence does ring like a doxic repetition: "Pornographers are the enemies of women [...]".

Judith Butler has strongly contributed to reviving the controversy by raising the crucial question of the performativity of injurious speech: "it is by being interpellated within the terms of language that a certain social existence of the body first becomes possible", Butler (1997: 5) argues. What she implies here, is that the threat contained in any combination of signs - be they pictorial or linguistic - only makes sense in terms of the act it prefigures. Catharine MacKinnon, a legal scholar, also argues that pornographic representations are performative: they do not simply state a point of view, they constitute a certain kind of conduct. Pornography is construed as both speech and conduct and is understood not only to act on women in injurious ways but to constitute the class of women as an inferior class. Words are not only words, they do things, as Austin's famous manual contends:

Pornography does not simply express or interpret experience, it substitutes for it. Beyond bringing a message from reality, it stands in for reality. [...] Pornography makes the world a pornographic place through its making and use, establishing what women are said to exist as, are seen as, are treated as, constructing the social reality of what a woman is and can be in terms of what can be done to her, and what a man is in terms of doing it. (MacKinnon 1993: 25)

What singles out Butler's approach is that she chooses to argue againts such a restrictive view of the performativity of injurious speech. She notes that pornography charts a domain of unrealizable positions and that the phantasmatic power of signs cannot, strictly speaking, constitute that reality. She then raises the possibility of "re-signification": speech remains speech, but this permits the threat to be countered by a different kind of performative, and Butler contemplates the possibility of a counter-speech, a kind of talking back that would also implicate the opening up of the possibility of an agency.

My aim in this paper is to add grist to Butler's mill, but also to suggest that the production of an agency can only be achieved if the talking back has a rhetorical dimension, that only rhetoric can constitute an appropriate tool to fight back the threat of injurious speech. 
It should first be noted that Carter completes her opening sentence in a way that nearly contradicts the first segment while at the same time providing the beginning of an explanation to the full title of the Preface ("Polemical Preface: Pornography in the Service of Women"):

Pornographers are the enemies of women only because our contemporary ideology of pornography does not encompass the possibility of change, as if we were the slaves of history and not its makers, as if sexual relations were not necessarily an expression of social relations, as if sex itself were an external fact, one as immutable as the weather, creating human practices but never a part of it.

What is implied here is that it is not pornography as such which should be indicted, but the perpetuation of a certain practice of pornography. What Carter unambiguously condemns, therefore, is the "ideology" that constrains the practical effectuations of sexual relations, an ideology which precludes pornographers from revisioning the order of things. Carter is not disgusted by the obscenity of the representation; nor is she offended by the commodification of woman: what fascinates her is what also fascinated Barthes (1994: 1136), namely the semiotic issue. In other words, pornography is the enemy of women only insofar as it is part of a global system of meaningmaking through which social positions are forcibly assigned to human agents. Her theory is very clear on this point: pornography does not produce exploitation; it is the social system ("social relations") that produces exploitation, along with a certain form of pornography. In that sense, pornography is only one specific expression of forceful subjectification. Although Carter seems to be very close to a Marxist position on this matter, her conception of ideology being redolent of Althusser's (1980: 59) view of ideological shifts as being subtended by les rapports sociaux, her analysis is more likely to be borrowed from Barthes's deconstruction of myths: pornography functions like a "myth" insofar as it expresses a given order to whose production it also contributes. For the principal function of myth, Barthes (1970: 193) contends, is to "naturalize", i.e. to transform into an inescapable set of "facts" what has always already been a system of values. Myths emerge in order to transform history into "Nature": they give the illusion that contemporary social practices are inscribed within a natural order of things.

Here, Carter goes one step beyond. Indeed, what both Althusser and Barthes fail to see is that the mythic order of things is inevitably constrained by gender relations. This time, Carter is much nearer to Michel Foucault. Like him (1976: 21), she does not consider that it is sexuality which conditions social practices, or intersubjective relations: sexuality is only the effect of a technique de pouvoir, a strategy of power. Sexual difference results from a mass of discourses which all ensure that one class, or one gender, dictates their 
vision of things to the other. In short, sexuality itself is an effect of discourse, a myth, and therefore a fiction, or to be more precise a semiological system. For Carter, a caricatural symbol of this discursive strategy is the pictorial representation of sexual intercourse on the walls of public lavatories. It appears that this "universal language of lust" (1993: 4) signifies masculinity through a penis in erection, and femininity through a gaping hole, as if it were in the nature of things that the masculine principle should be represented by a form of affirmation and the feminine principle by "an inert space" "like a mouth waiting to be filled". Sexuality, we infer, is "mythologized" when it is constrained by ideological representations of sexual difference which take it for granted that masculinity should be active and femininity passive. The most basic representation of sexual intercourse obeys a prescriptive discourse which distributes functions and positions in an imperative, quasi "natural" manner. This valorization of discourse is central to my critique of Carter's theory.

For the most interesting point here is that pornography seems to be placed outside the field of morality, which of course will later invalidate Carter's vindication of Sadeian literature. Pornographic representation is conceived of in terms of semiotics. To represent woman by nothing but "a fringed hole" (1993: 4) and man by nothing but "the probe", i.e. "his prick", is not simply to reproduce an anatomical difference: it is to coin specific markers of masculinity and femininity in a process that implies the use of a specific language. I am here coming to the rhetorical dimension of obscene graffiti according to Carter, a crucial stage in my deconstruction of her theory. My contention here is that both sexes are linguistically constructed thanks to a well-known trope which consists in substituting the part for the whole: this is evidently the case of the synecdoche, a form of metonymy. This unconscious use of the metonymic mode does not contradict Carter's overt ambition. On the contrary, this rhetorical strategy fulfils its ideological function perfectly: the metonymic representation of sex is itself a technique of power since femininity will make sense only insofar as it is related to the signifier of masculinity. The male organ is here to fill the hole, the nothingness of femininity to which it functions not only as a complement but also as an essential justification. As Carter bluntly puts it, still on the same page: "Woman is negative. Between her legs lies nothing but zero, the sign for nothing, that only becomes something when the male principle fills it with meaning". One signifier can only be legitimized by the presence of the other signifier, or the signifier of the other, without which woman's right to existence seems to be denied.

The fictional implications of this linguistic construction of gender need to be explored. For if femininity cannot come to full presence before her compulsory reference to the male principle is made clear, it follows from this that femininity cannot exist as long as it is not integrated into a story. Indeed, 
as in all naïve stories (Kermode 1979: 6-7), femininity is produced through a beginning - the meaningless hole-, a middle - the sudden appearance of "the probe"-, and an end-the mouth is bound to be filled. As a matter of fact, the "myth of patience and receptivity" (Carter 1993: 5) assigns femininity to residence both temporally and spatially. On a spatial plane, femininity is on the side of the static and the dead: it is inert, passive matter, offered up to masculine exploitation. On a temporal plane, femininity exists only as a non-agent, waiting to be animated and granted a structural significance through the providential intervention of the filling agent. Both temporally and spatially, femininity's presence is therefore perceived as something-in-waiting. Her truth, the revelation of her true essence, is therefore of a storied nature. We are here beginning to see the relation between Carter the essayist and Carter the novelist: if femininity is produced by a narrative strategy, characterized by the use of specific tropes, if there is indeed a mythos of woman's position among the other humans, then a woman's "self" is not a pure, transcendental reality, but the mythical conjugation of a rhetorical effect and of a plot. The synecdoche is not simply a figure of speech: it is also the promise of a story in which femininity is to be denied centre stage. In the process of the "mythic generation of femininity" (Carter 1993: 4-5), the signifier is always already caught within an endless chain of metonymic appearances whose ultimate referent is bound to be for ever deferred.

It now becomes easier to understand why Carter polemically refused to condemn pornography as such. What she really contests is a certain naive, caricatural emplotment and stylisation of femininity, as it expresses itself in low-rate pornography. Her defence of the marquis de Sade is to be analized from this perspective. But one should also note that Carter is certainly not trying to defend a literary canon. She does not hesitate to claim that there is very little difference between what is offensively scrawled on a urinal wall and what is officially consecrated in an academic assignment including the story of Oedipus (1993: 22-23). This very interesting parallel, contentious as it may appear, enables us to understand what Carter really means by "demythologization". What she has in mind, I shall now try to demonstrate, is a revision of femininity.

A detour through a later article will prove necessary here. Carter (1983: 38) takes up her indictment of "the social fictions that condition our lives". What becomes much more explicit, however, is the importance she now grants to the practice of writing itself, not only to the intellectual deconstruction of the process of "mythic generation". The famous novelist she has now become suddenly chooses to sketch a self-portrait of the feminine artist: "I'm in the demythologizing business" (1983: 38). The critic is very often content with this short, cryptic formula, which paradoxically enough is very rarely commented upon. A few lines further down, Carter explains that "writing fiction as a 
woman" should consist in striving to free oneself from the myths inherited from the androcentric or phallocentric tradition. But, at the same time, she introduces a slightly disturbing notion: for her, "writing fiction as a woman" should consist in seeking to produce a new vision of femininity, a revision of femininity, which, according to her, can only be the business of the "creative artist". In other words, Carter's programme of "demythologization" concerns primarily creativity, i.e. a linguistic operation. The artist cannot rest content with publicly denouncing inequalities, criticizing existing structures of feeling, or even displaying her capacities as a feminist semiotician. She must act, force the enemy out, reappropriate a vital space. She must find a linguistic posture ("writing as a woman"), invent a semiotic position, which demands that she produce new ways of meaning-making. What is implied is that the decolonization of discourse should have the capacity to reinscribe the experience of sexual difference within a new system of relations between the signifiers, within a new mythos of differentiation, within a new fiction of difference. Interinstingly, this is how Carter (1983: 42) sums up the operation:

I personally feel much more in common with certain Third World writers, both female and male, who are transforming actual fiction forms to both reflect and precipitate changes in the way people feel about themselves-putting new wine in old bottles and, in some cases, old wine in new bottles.

What emerges from the first segment of the quotation is that there can be no essentiality of "feminine writing". There are only minorities, both female and male, whose business it is to operate changes in perceptions of the self and in intersubjective relations. What matters for Carter, therefore, is a positioning of the self, a posture, a process of subjectification, which is dictated neither by biology nor by culture, but by the effect of fiction. For to "transform fiction" is also to change structures of feeling and forms of intersubjectivity. Writing "precipitates changes". Of the means required in view of this achievement, Carter gives apparently no clear indication. My contention it is, though, that the way the message is formulated is in itself an answer to the question raised. I take the end of the quotation to be a crucial clue in Carter's theory of writing.

Note first that in order to illustrate her theory she uses a metaphor, or rather a complex metaphorical cluster: "putting new wine in old bottles and [...] old wine in new bottles". I choose to leave aside the overtones of swindling implied in the image-a choice that deliberately takes me away from the issues of commodification of mythology and therefore from one of the most common features of postmodernist criticism today-in order to concentrate on the inner workings of the image. A quick reading of this cryptic formula will give the unfortunate impression that Carter seeks to reactivate the 
age-old distinction between form and contents, or container and contained. Arguably, the "new wine" of the first metaphor may stand for new forms of amorous play, and the "old bottle" may very well refer to the traditional forms of literary production likely to accommodate such "revisions". In the same spirit, the "new bottles" of the second metaphor would stand for the new forms of expression available on the contemporary literary market, and the "old wine" would then refer to classic intersubjective relations. This interpretation may appear acceptable, but to me it is irrelevant.

First, the metaphorical cluster conjugates two rhetorical devices which we should normally expect to be firmly dissociated: for the two metaphors imply a metonymic form of association which is now intellectually unacceptable. We must bear in mind Carter's strong diffidence about synecdoches, figures of $s$ peech that are used to mean the whole through the part, but also sometimes the container for the contained, and vice versa. In Carter's formula, it is expected that the contained take on its true meaning from its relation of contiguity to the container, in the way the single organ used to refer to the whole body. Here, however, this type of association is exposed as curiously disjunctive. We are quite ready to accept the idea that the pornographic graffiti function on a relation of necessary complementariness between the two signifiers, but it seems highly questionable that an old wine will owe its specificity to a new bottle! Nor has there ever been evidence of a new wine having its characteristics changed by being poured into an old bottle... In other words, no "mythic" system of meaning will help us here. This is not only solid (French) common sense: Barthes (1970: 234) used to repeat that mythic explanations are always stalemated whenever the language of the maker or the language of the producer makes itself heard. The maker knows that myths will not do when real work is required. Interestingly, Barthes defines this kind of practical language as a "revolutionary" intervention of the maker: the revolutionary knows that things do not always fall into mythically predetermined patterns and that sometimes pragmatic operations produce "a truth" obscured by mythic discourse.

The revolution Carter seems to be concerned with does not imply physical action: she knows that one can do things with words. She knows that her rejection of mythic explanations of femininity may produce a "truth" a fictional truth whose pragmatic impact may be as great as any other action. In fact, her complex nexus of incongruous metaphors engages the reader to think differently, to break free from myth, and finally to produce a new fiction of the self and of intersubjectivity. The fiction the reader is thus expected to produce in the act of reading is one that violently disrupts the mythology of metonymic relations. For, in violation of all the most basic laws of (French) oenology, each of Carter's disturbing metaphors pulverizes the classical notion of the metaphor as a "borrowed container": instead, she suggests an 
impossible truth, something like a qualitative porosity between the container and the contained. The old container transfigures the new liquid, and the old liquid is transfigured by being rebottled-a miraculous, purely performative event which establishes a form of fluidity between the signifiers. The metonymic relation seems to be contaminated by a more modern metaphorical principle, according to which poetic might can only be produced through the dynamic, agonistic interaction of two signifiers (Black 1979: $19 \mathrm{ff}$.). The reader is therefore invited to imagine this extremely puzzling case: form may change the very nature of things; conversely, the contained may transform the shape of the container, in a kind of amorous play in which all strategies of power have been abolished. What remains is a linguistic game, which operates as a play of instability and interchangeability.

We may now return to the "Polemical Preface". What Carter's rhetorical and pragmatic logic invites us to to think is that a "demythologization" of sexual difference can only rest on a semiotic achievement, that a revisionist rejection of traditional assignations to residence can only take place in the sphere of linguistic games. Carter's joint indictment of pornography and semiotic rehabilitation of Sade could only run up against the Anglo-Saxon feminist doxa of the day. But seen from our angle (one that is undoubtedly influenced by the French philosophy of the late sixties and early seventies), pornography is not morally condemnable: it simply makes visible the structure of gender relationships. What a man does to a woman in a pornographic film is another version of what inscribes itself universally on urinal walls-a metonymic positioning of femininity. If pornography has not changed, it is according to Carter (1993: 17) simply because it has failed to acknowledge the possibility that techniques and strategies of power can be redefined. For Carter, pornography is therefore nothing but a metaphor of intersubjective relations, one that has forgotten its metaphorical quality, one that has therefore perpetuated a "mythology". Pornography is a metaphor that has ended up taking the metonymic representation of femininity for the truth of femininity. Here, we are very close to what seems to be the major philosophical assumption of Carter's essay: the myth of femininity thrives on the effacement of metaphorical consciousness, an effacement which gives metonymy free rein to pass for the truth of gender relations. This is what fascinates Carter in her analysis of Sade's literature. Sade's pornography refuses the mythic dimension of gender positioning. His pornography can therefore be said to be "moral":

The moral pornographer would be an artist who uses pornographic material as part of the acceptance of a world of absolute sexual licence for all the genders, and projects a model of the way such a world might work. (1993: 19) 
When positions are redistributed by linguistic games, when postures break free from myth, pornography can be revolutionary, or to take up Carter's words "a revisionary exercise in the service of women". What Carter calls pornography is nothing but a semiotic arrangement. And what she understands by moral has nothing to do with the distribution of good and evil. What she has in mind is what, following Greek etymology (ethos: a way of life), I would call an ethical operation. A revolutionary semiotic arrangement is meant to dislocate mythic assignations to residence and to provide the feminine with a new home, with a new modality of being.

Let me now recapitulate my argument through five propositions:

1) Angela Carter theory of pornography rests on one basic assumtion, namely that the order of things is a sexual order which mythology has always legitimized.

2) This first proposition implies a corollary: the order of things is in fact an effect of myth, i.e. a product of discourse. Intersubjective relationships, and the play of sexual difference itself, are nothing but a discursive reality.

3) There is no dissociating myth from literature, or literature from myth: therefore, the work of "demythologization" can only be achieved through a literary event, and more precisely through a rhetorical game.

4) Judith Butler is right when she asserts that the speaking subject makes his or her decision only in the context of an already circumscribed field of linguistic possibilities, but, following in Carter's footsteps, I suggest that the necessary response to injurious language can break free from the violence of mimetic rivalry only when the production of agency is supported by innovative rhetoric.

5) Carter is wrong to call Sade's experiments "moral pornography". Experimental writing, or even an intertextual use of pornography, is not pornographic. The revolutionary redistribution of postures is first and foremost a semiotic experience. This experience is not moral, but ethical: rhetoric may not only rework pornography within a feminist project, it may also redefine postures in intersubjective relations. 
FREDERIC REGARD

\section{REFERENCES}

Althusser, Louis. 1980 (1965). Pour Marx. Paris: Maspéro.

Carter, Angela. 1993 (1979). The Sadeian Woman. An Exercise in Cultural History. London: Virago.

Carter, Angela. 1997 (1983). "Notes from the Front Line". Shaking a Leg. Collected Journalism and Writings. London: Chatto and Windus.

Barthes, Roland. 1970 (1957). "Le Mythe aujourd'hui". Mythologies. Paris: Editions du Seuil.

Barthes, Roland. 1994 (1971). Sade, Fourier, Loyola. Oeuvres complètes. Paris: Editions du Seuil. Vol. II.

Black, Max. 1993 (1979). "More about Metaphor". Metaphor and Thought. Ed. A. Ortony. Cambridge: Cambridge University Press.

Butler, Judith. 1997. Excitable Speech. A Politics of the Performative. New York and London: Routledge

Foucault, Michel. 1976. La Volonté de savoir. Paris: Gallimard.

Kermode, Frank. 1979 (1966). The Sense of an Ending. Studies in the Theory of Fiction. Oxford: Oxford University Press.

MacKinnon, Catherine. 1993. Only Words. Cambridge, Mass.: Harvard University Press. 